\title{
Variability in Stage I egg production and settlement of plaice Pleuronectes platessa on the west side of the Isle of Man, Irish Sea
}

\author{
Richard D. M. Nash*, Audrey J. Geffen \\ School of Biological Sciences, University of Liverpool, Port Erin Marine Laboratory, Port Erin, Isle of Man IM9 6JA, \\ United Kingdom
}

\begin{abstract}
The variability in Stage I egg production and subsequent settlement of plaice Pleuronectes platessa $\mathrm{L}$. on the west side of the Isle of Man, Irish Sea, was investigated over the period 1992 to 1998 . This small spawning ground contributed approximately $0.6 \%$ of the total plaice egg production in the northern Irish Sea for 1995. The timing of peak egg production varied between years from approximately the middle of February to the end of March. The timing of peak egg production was related to the mean autumnal water temperature, with earlier spawning in warmer years. Egg production on the west side of the Isle of Man in 1995 was earlier than in the eastern Irish Sea, probably reflecting the slightly warmer water conditions in the central Irish Sea. The estimated Stage I egg production varied considerably between years, differing by a factor of 2.8 over all years. There was a positive relationship between the annual egg production and the numbers of individuals settling in Port Erin Bay. Interannual variation in abundance was greater at settlement than in either Stage I eggs or the size of the juvenile population in July. Higher inter-annual variability in the pelagic phase is dampened during the nursery ground phase.
\end{abstract}

KEY WORDS: Irish Sea $\cdot$ Plaice $\cdot$ Egg production $\cdot$ Settlement $\cdot$ Variability

\section{INTRODUCTION}

In much of the research on stock and recruitment, spawning stock biomass is assumed to be an indicator of egg production (Marshall et al.1998). In fact, Stage 1 egg production is often used as a fishery independent estimator of spawning stock biomass (e.g. Anonymous 1997). However, Marshall et al. (1998), used cod Gadus morhua as an example to demonstrate that feeding conditions and age structure of the population can affect egg production. They also show that, in cod stocks at least, egg production for a given spawning stock biomass can vary by a factor of 2 in adjacent years. In the case of plaice, Rijnsdorp (1991) and Rijnsdorp et al. (1991) have demonstrated that long term changes in fecundity and variations in size or age at first maturity can influence the numbers of eggs

·E-mail: rdmnash@liv.ac.uk spawned per unit biomass of spawning stock. Nash (1998), using a standard fecundity per unit length, showed variability in egg production based on the age structure of Irish Sea plaice. The viability or quality of eggs over the short term due to changes in population condition or age structure has not received much attention.

Year class strength for plaice in the North Sea is generally thought to be determined in the planktonic phase, during the egg and larval periods (Zijlstra \& Witte 1985, van der Veer 1986). In general, predatory and feeding conditions are thought to be the main factors determining survival (Shelbourne 1957, Harding et al. 1978, Pommeranz 1981, Hovenkamp 1989, 1990). Survival, and consequently the numbers of individuals arriving on the nursery grounds, is partially influenced by transport mechanisms from the spawning to nursery grounds (Pihl 1990, van der Veer et al. 1990, 1998, van der Veer \& Witte 1999). In many of the pelagic survival models presented by Nash (1998), there was a clear 
linear relationship between the numbers of eggs spawned and the numbers of individuals at metamorphosis. In contrast to some earlier work, these models generally suggest that processes affecting survival of plaice in the pelagic stage cause only minor alterations to the ranking of high and low settlement years from a given number of eggs laid.

The spawning grounds for plaice Pleuronectes platessa L. in the Irish Sea are well documented (Simpson 1959a). The main spawning grounds in the ICES Division VIla are off St. Bees Head, southeast of the Isle of Man, off Great Orme Head, western Irish Sea (along the central-eastern Irish coast) and Cardigan Bay. Ellis \& Nash (1997) also showed a small spawning ground on the west side of the Isle of Man. There are fewer studies on the spawning period of plaice in the Irish Sea (Simpson 1959a, Harding \& Talbot 1973, Nichols et al. 1993, Ellis \& Nash 1997, Anonymous 1997) compared with the numerous studies in the North Sea (e.g. Simpson 1959b, Harding et al. 1978, Coombs et al. 1990, Rijnsdorp 1991, Rijnsdorp \& Vethaak 1997).

In the Irish Sea the eggs are not transported far from the spawning grounds (Simpson 1959a, Anonymous 1997) and the spawning grounds are generally close to the nursery grounds (Riley et al. 1986, Anonymous 1997). In the Irish Sea the effects of variable transport mechanisms may not be as influential as in the North Sea due to the relatively short distances between spawning and nursery grounds. Based on Stage I egg production, peak spawning of plaice in the Irish Sea is generally in mid-March (Simpson 1959a, Anonymous 1997, Ellis \& Nash 1997), which is similar to the pattern in the Celtic Sea (Horwood 1993a) but 4 to $6 \mathrm{wk}$ later than in the Southern Bight of the North Sea (Harding et al. 1978)

Virtual population analyses (VPA) of Irish Sea plaice indicate that there were only small changes in the spawning stock biomass between 1991 and 1997 (Anonymous 1998). Therefore, if SSB is directly related to egg production there should be only minor interannual differences in the abundance of Stage I eggs over this time period

In this study we examine the interannual variability in Stage I plaice egg production in relation to the estimated spawning stock biomass and timing of peak egg production from the spawning site on the west coast of the Isle of Man. We also examine the hypothesis that the production of Stage I eggs in plaice is a good predictor of the numbers of plaice surviving through the pelagic phase to settle on the nursery grounds, by comparing the egg production on the west side of the Isle of Man with settlement indices in Port Erin Bay, Isle of Man. Finally, we examine differences in interannual variability of the different indices which represent dis- tinct life history stages, i.e. spawning stock biomass to maximum measured population size on the nursery ground in July each year.

\section{MATERIALS AND METHODS}

Pelagic stage. Plaice eggs were sampled with an unencased Gulf VII high-speed plankton sampler (Nash et al. 1998). All tows were double oblique. In 1992 to 1995 and 1998 a CTD cast (SeaBird SeaCat SBE-19, SeaBird Electronic Inc., USA) was made at each station (see Ellis \& Nash 1997). In 1996 and 1997 a series of 33 CTD stations (see Fig. 1) was undertaken. the day before plankton sampling to estimate mean water temperature across the area sampled. The same set of stations was sampled from 1992 to 1995 (see Ellis $\&$ Nash 1997). The number of stations was increased and the positions altered slightly from 1996 to 1998 (see Fig. 1).

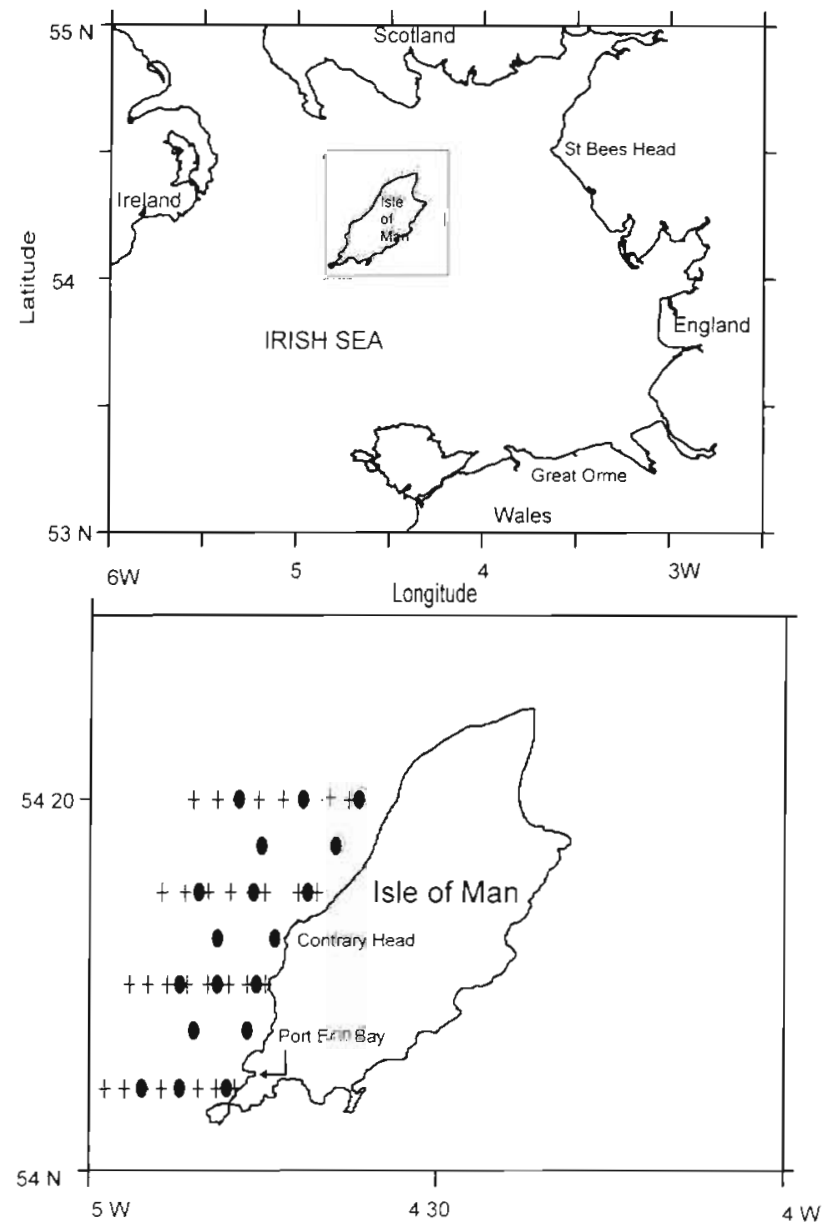

Fig. 1 Positions of plankton sampling stations (Gulf VII plus CTD) (1) and CTD only stations (+) for the period 1996 to 1998 on the west side of the Isle of Man, Irish Sea 
Between 1992 and early 1995, a $50 \mathrm{~cm}$ Gulf VII highspeed plankton sampler with a $20 \mathrm{~cm}$ diameter nose cone and a $333 \mu \mathrm{m}$ mesh net was used. Volumes of water sampled were estimated from mechanical flow meters in the mouth of the nose cone (see Ellis \& Nash 1997 for further details). Between 1994 and 1995 the maximum depth of the sampler was estimated from a FURUNO net sonde attached to the top side of the sampler. Between late 1995 and 1998, a $7.0 \mathrm{~cm}$ Gulf VII/PRO-NET highspeed plankton sampler (Nash et al. 1998) with a $40 \mathrm{~cm}$ nose cone was used. Maximum depth and volume filtered were recorded by the PRO-NET system. In all cases, sampling commenced each year in January or as soon after as weather permitted, and continued at intervals of approximately 2 wk until June.

Upon recovery of the sampler the net was gently hosed down with seawater and the contents of the cod end preserved in $4 \%$ freshwater buffered formaldehyde. Plaice eggs were identified according to Russell (1976) and were allocated to stages of embryonic development (I to V) according to Apstein (1909) and Ryland et al. (1975). No attempt was made to distinguish between Stages IA and IB.

Contour plots of the distribution of Stage I plaice egg densities (eggs $\mathrm{m}^{-2}$ ) on the west side of the Isle of Man were made using SURFER (ver. 6.03 Golden Software Ltd). The kriging option was used to generate the grid files. Estimates of daily production of Stage I plaice eggs were made assuming all stations were contained within 1 stratum. The numbers of Stage I eggs present on a survey date were estimated from the mean abundance of all stations (with its associated variance). The total numbers of Stage I eggs were converted into a daily Stage I egg production using the average water temperature and the Stage I egg duration (see Anonymous 1997, Nash 1998). The annual Stage I egg production was calculated by assuming that the estimate for a single sampling date was indicative of the egg production for the period from midway between the previous and the next sampling date (see Anonymous 1997). Thus daily Stage I egg productions could be summed over the entire period to obtain annual egg production. The variance of this estimated annual egg production was calculated as the weighted sum of the survey variances. The number of days included for each survey estimate in the overall production estimate was used as the weighting factor. The data from Ellis \& Nash (1997) were recalculated to make them compatible with the rest of the data set. Stage duration was calculated from the area weighted mean temperature in the water column from the CTD casts. There was no stratification of the water column at this time of the year. The timing of peak egg production was estimated by calculating the date of $50 \%$ of the cumulative egg production in each year $\left(\operatorname{Prod}_{50}\right)$. This method was judged better for interannual comparisons of the survey data than using maximum Stage I egg abundance data. Prod ${ }_{50}$ was calculated from polynomial curves $\left(N=\alpha+\beta \times\right.$ day $+\gamma \times$ day $^{2}+\delta \times$ day $^{3}$, where day is number of days from January 1, assuming a normal distribution in time) fitted to the Stage I egg production each year. Curves were fitted using GRAPHER (Golden Software Ltd)

Settlement of plaice in Port Erin Bay. Estimates of the number of newly settled plaice were obtained in Port Erin Bay between 1990 and 1998. For the years 1990 to 1994 the numbers of individuals $<17 \mathrm{~mm}$ long in the bay were estimated from a regular trawling series ( 5 parallel transects at right angles to the beach), using a $1.5 \mathrm{~m}$ beam trawl with a $3 \mathrm{~mm}$ mesh net throughout. The numbers of individuals per square metre were estimated from the length of tow, with a presumed 30\% capture efficiency (Macer 1967) applied to the numbers caught. The average density, calculated for each transect, was raised to the total area sampled. This was taken as the total number settling per day. Between 1995 and 1998 a small D-net $(0.33 \mathrm{~m}$ wide, Hastings 1980$)$ was used in shallow water to estimate settlement. Estimates from five $30 \mathrm{~m}$ tows were averaged to give an estimate of density and an associated variance. The total settlement was estimated in a similar manner as Stage I egg production (settlement per day for each sampling date and summed over the whole settlement period, see above). The settlement index variance was calculated as the weighted sum of sampling variance, as described above. A series of drop-trap samples were taken in tandem with the D-net samples in 1997. The drop-trap is assumed to have an efficiency of close to $100 \%$ (see Wennahage et al. 1997) and there were no significant differences between estimated densities from the drop trap and the D-net. The density estimates from the $D$-net samples could then be raised to the area occupied by settling plaice in Port Erin Bay. The beam trawl and D-net catches provide an index of settlement in the Bay.

\section{RESULTS}

\section{Plaice egg production on the west side of the Isle of Man}

The centre of Stage I plaice egg production on the west coast of the Isle of Man was similar in all years (1994 to 1998), in the vicinity of Contrary Head (Fig. 2). These distributions are similar to those recorded by Ellis \& Nash (1997) in 1992 and 1993. In general, plaice eggs were restricted to the inshore coastal waters Very few Stage I plaice eggs occurred in water $>50 \mathrm{~m}$ 

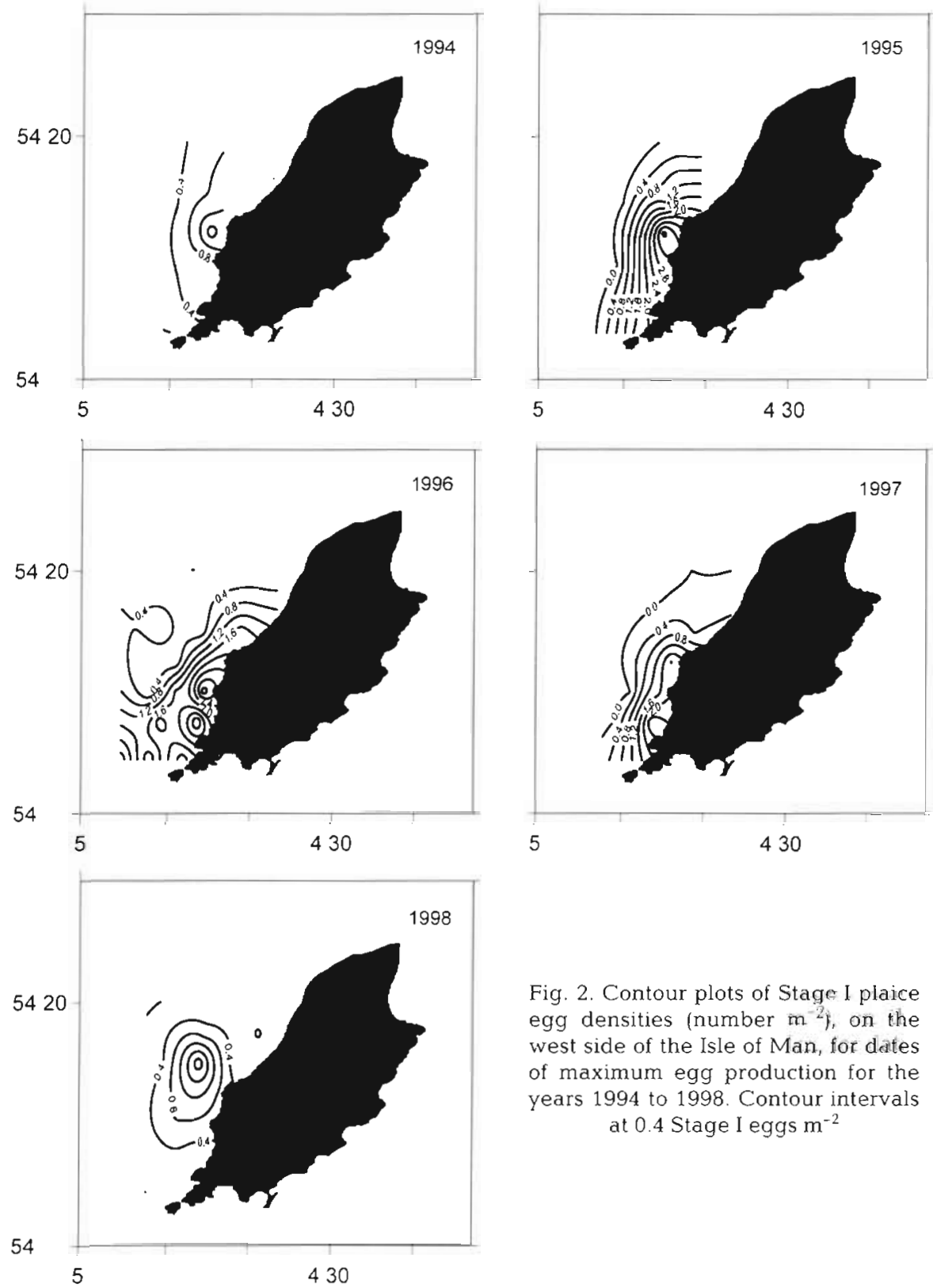

Fig. 2. Contour plots of Stage I plaice egg densities (number $\mathrm{m}^{-2}$ ), on the west side of the Isle of Man, for dates of maximum egg production for the years 1994 to 1998 . Contour intervals at 0.4 Stage $\mathrm{l}$ eggs $\mathrm{m}^{-2}$

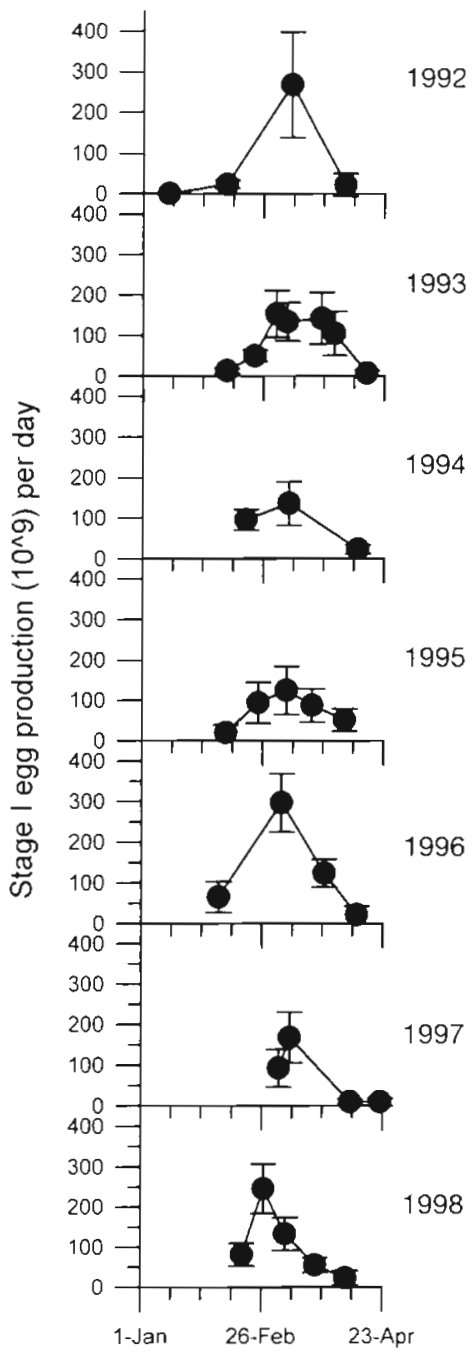

Fig. 3. Temporal distribution of Stage I plaice egg production for the years 1992 to 1998 on the west side of the Isle of Man. $1 \mathrm{SE}$ is shown depth. The most complex distribution pattern occurred in 1996, when elevated abundances occurred to the south west of the Isle of Man.

Plaice spawn along the west side of the Isle of Man between mid-February and mid-April. The timing of egg production varied between 1992 and 1998 (Fig. 3). The earliest peak (around 21 February) occurred in 1998 , coinciding with exceptionally high winter water temperatures (Table 1). The latest peak occurred around 27 March in 1993. Prod 50 , the date of $50 \%$ egg production, varied by $22 \mathrm{~d}$ and was related to water temperature during the previous autumn and winter (Fig. 4a). Generally, warm autumn to winter water temperatures were followed by earlier spawning.
Data for Stage I plaice egg production in the eastern Irish Sea was obtained from Anonymous (1997) (Fig. 5). The eastern Irish Sea plaice egg production curve was similar to that of the west side of the Isle of Man. However, the peak in plaice egg production on the west side of the Isle of Man occurred approximately $9 \mathrm{~d}$ earlier. Considering the sampling frequency and the fact that the data for the eastern Irish Sea were collected over a 3 to $4 \mathrm{~d}$ period, there may be no difference in the timing of peak egg production. However, the depth integrated temperatures for the Irish Sea (Anonymous 1997) indicate that the eastern Irish Sea was colder during the 1995 spawning period than the west coast of the Isle of Man, 
Table 1. Mean monthly sea surface temperature $\left({ }^{\circ} \mathrm{C}\right)$ for February to April in Port Erin Bay, Isle of Man, between 1992 and 1998. Data supplied by T. Shammon (Port Erin Marine Laboratory, Port Erin, lsle of Man)

\begin{tabular}{|lccccccc|}
\hline & 1992 & 1993 & 1994 & 1995 & 1996 & 1997 & 1998 \\
\hline Feb & 7.96 & 7.31 & 6.75 & 8.05 & 7.08 & 7.56 & 9.08 \\
Mar & 8.01 & 7.05 & 7.05 & 7.38 & 6.89 & 7.76 & 8.85 \\
A.pr & 8.28 & 8.10 & 7.39 & 8.37 & 7.72 & 8.26 & 9.02 \\
\hline
\end{tabular}

which may explain the slight difference in peak egg production.

Stage I egg production on the west side of the Isle of Man was compared with the rest of the Irish Sea for 1995. The total seasonal production of Stage I eggs in the study area off the west coast of the Isle of Man in 1995 was equivalent to $1.58 \%$ of the total production in the eastern Irish Sea, or $0.60 \%$ of the total production in the northern Irish Sea (excluding Cardigan Bay).

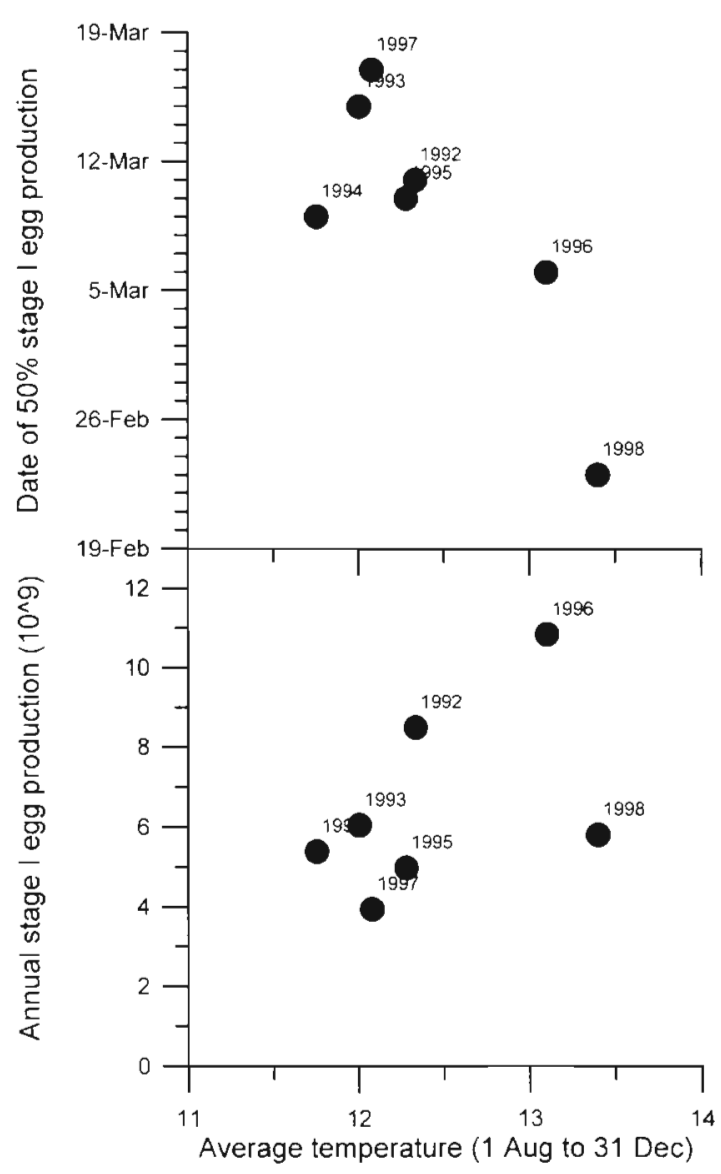

Fig. 4. The influence of the mean autumnal and early winter sea surface temperature (data from Port Erin Bay, Isle of Man) on (a) timing of $50 \%$ of Stage I egg production and (b) the annual Stage I egg production on the west side of the Isle of Man (1992 to 1998)



Fig. 5. Stage I plaice egg production in 1995 for the west side of the lsle of Man (West IOM) and for the eastern Irish Sea (Eastern IS)

There was considerable variation in plaice egg production on the west side of the Isle of Man between 1992 and 1998, > 2.5 $\times$ during the 7 yr period (Fig. 6a). There appeared to be a small decline in Stage I egg production between 1992 and 1995. Very large Stage I egg production occurred in 1996, followed by egg productions similar to the preceding years. There may be a weak relationship between Stage I egg production and pre-spawning temperature (Fig. 4b). However, there was no significant relationship between the mean temperature during the gonadal development and maturation period for adults and the level of egg production $\left(F_{1,6}=0.152 ; \mathrm{p} \geqslant 0.05\right)$.

\section{Plaice settlement in Port Erin Bay}

Between 1990 and 1998 in Port Erin Bay there were 2 yr with large numbers of juvenile plaice at settlement, 1992 and 1996 (approximately 3.5 times the average for the other years) (Fig. 6b). Settlement in 1990-1991 and 1993-1995 was remarkably constant. The years 1997 and 1998 indicate lower numbers of individuals settling in Port Erin Bay. The timing of $50 \%$ of settlement in Port Erin Bay has varied by only approximately 2 wk, 11 to 27 May.

In general, higher plaice egg production on the west coast of the Isle of Man led to higher numbers of individuals settling in Port Erin Bay (Fig. 7). There was a significant linear relationship: 
Settlement $_{\text {Port Enn Bay }}=$

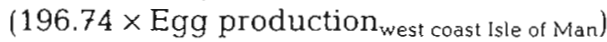

$-586.18\left(F_{1,6}=33.703 ; \mathrm{p}=\leq 0.01\right)$

where Stage I egg production is $10^{9}$ and settlement index is $10^{3}$. The 1998 data set is the only one for which standard errors do not intersect the fitted regression line.

There did not appear to be any relationship between the time of $50 \%$ of Stage I egg production and the time of $50 \%$ settlement (Fig. 8). This could be due to differences in the pelagic stage duration, which varies between years as a function of the thermal regime. The pelagic stage duration varied between 58 and $81 \mathrm{~d}$, but

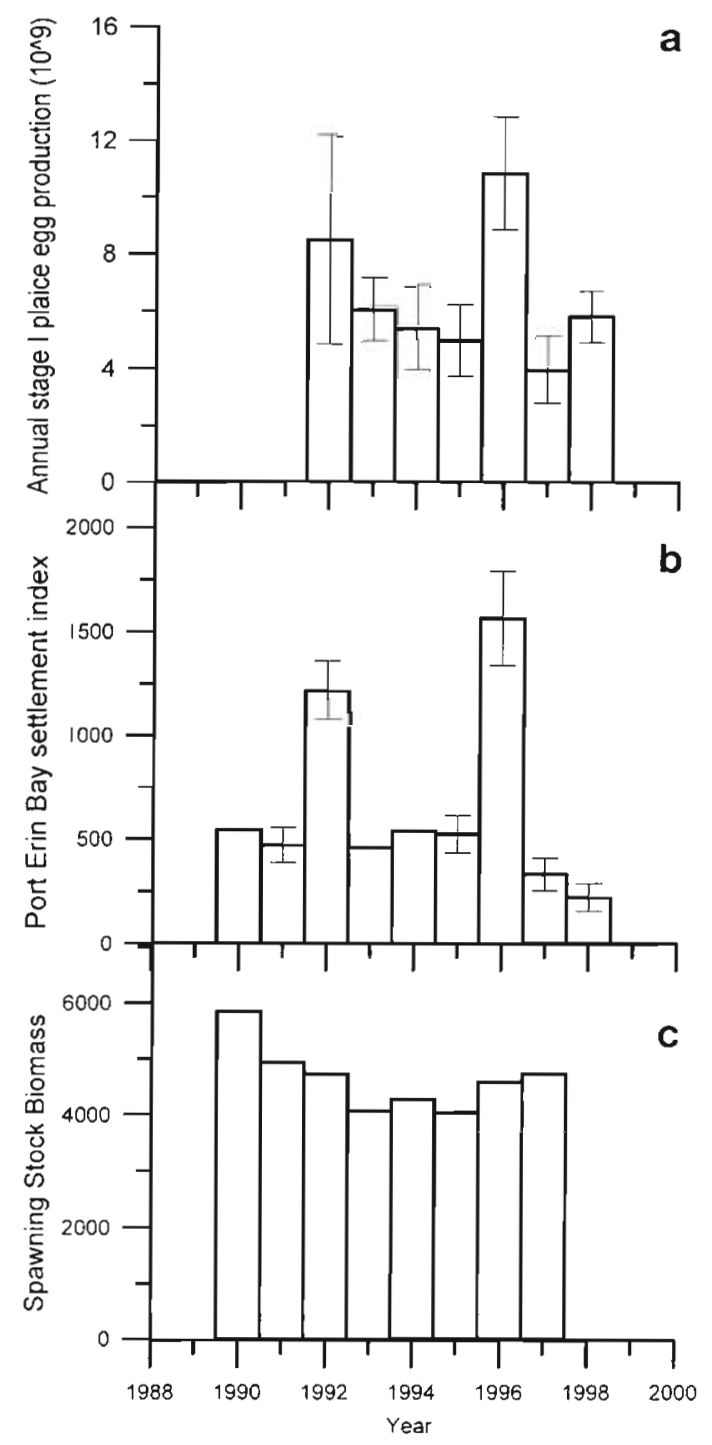

Fig. 6. Annual variations in (a) annual Stage I plaice egg production (1992 to 1998) for the west side of the Isle of Man, (b) settlement of plaice on the Port Erin Bay nursery ground, and (c) spawning stock biomass in the Irish Sea (Division VIIa). Error bars: $1 \mathrm{SD}$

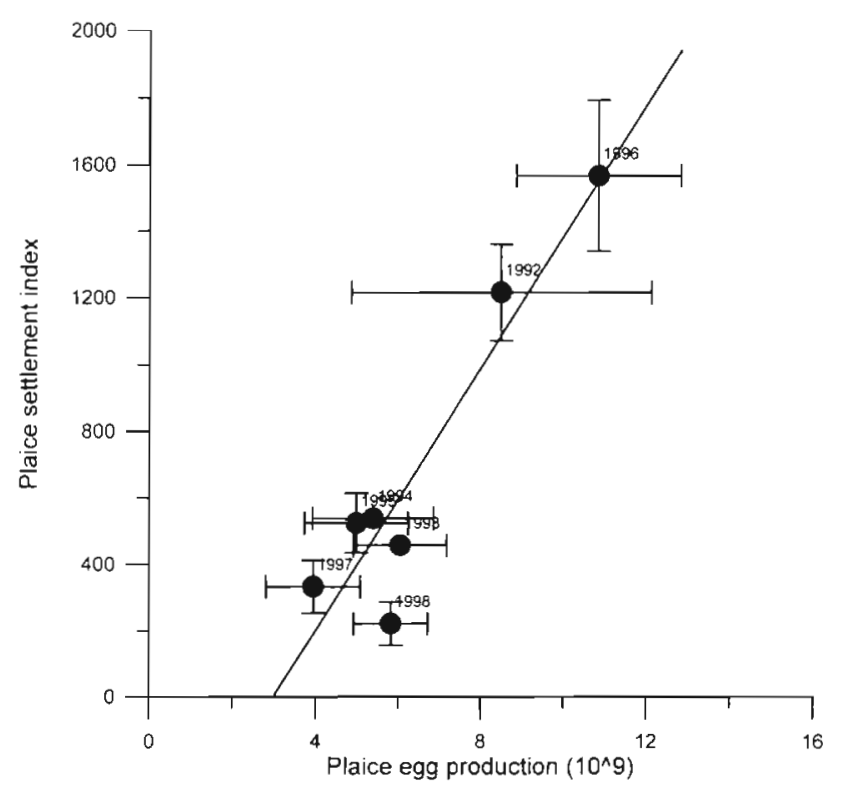

Fig. 7. Relationship between annual Stage I plaice egg production on the west side of the Isle of Man and the numbers of juvenile plaice which settle on the Port Erin Bay nursery ground. Error bars: $1 \mathrm{SE}$

was not significantly related to the water temperature in March (spawning time) nor the water temperature in late May (mid settlement time) (Fig. 9). Except for 1998, when offshore and May water temperatures were considerably higher than other years, pelagic stage duration tended to be shorter in years with faster warming over the main part of the pelagic phase (Fig. 10).

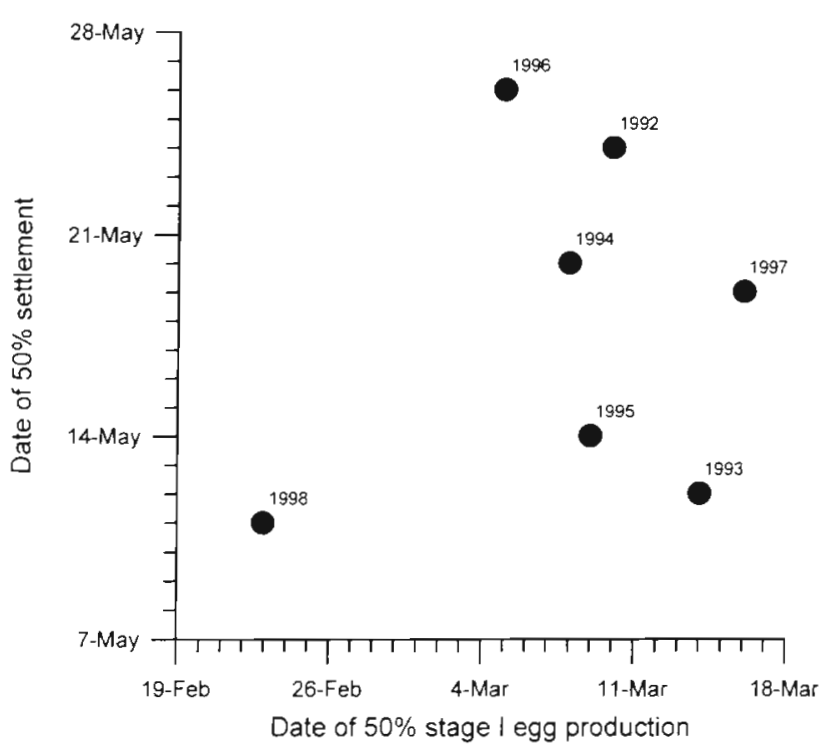

Fig. 8. Relationship between the date of $50 \%$ of Stage I egg production on the west side of the Isle of Man and the date of $50 \%$ of settlement in Port Erin Bay, Isle of Man 

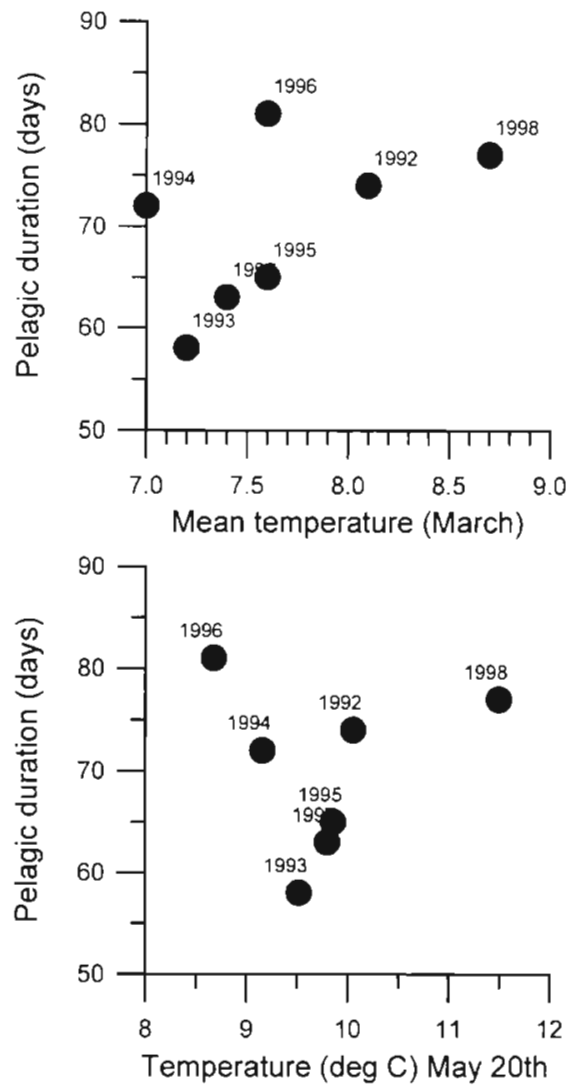

Fig. 9. Relationships between sea temperature and pelagic duration of young plaice on the west side of the Isle of Man. (a) Mean temperature for the survey (depth averaged) where maximum Stage I egg production occurred. (b) Sea surface water temperature on May 20 in Port Erin Bay, Isle of Man

\section{Interannual variability at different life stages}

Over the study period (1992 to 1998) the coefficient of variation ( $\mathrm{CV}$ ) in Stage I egg production on the west coast of the Isle of Man was 36\% (Table 2). The interannual variability was higher for Stage I egg production than for the estimated spawning stock biomass for the same period (See Fig. 6a,c). A similar pattern and range in CVs is seen in the available data for the Southern Bight of the North Sea (Table 2). The variability in abundance in the Irish Sea (Port Erin Bay) was greater at settlement than at earlier stages, or later in the season (July). The ratio of the highest and lowest abundances shows that Stage I egg production can vary by a factor of approximately 3, settlement by a factor of 7 which is reduced to a factor of 5 by July. On the Wadden Sea nursery grounds interannual variation (CV) similar to that in the Irish Sea was seen in the settlement/peak data. However, the variation in July was considerably lower in the Wadden Sea than in Port Erin Bay.

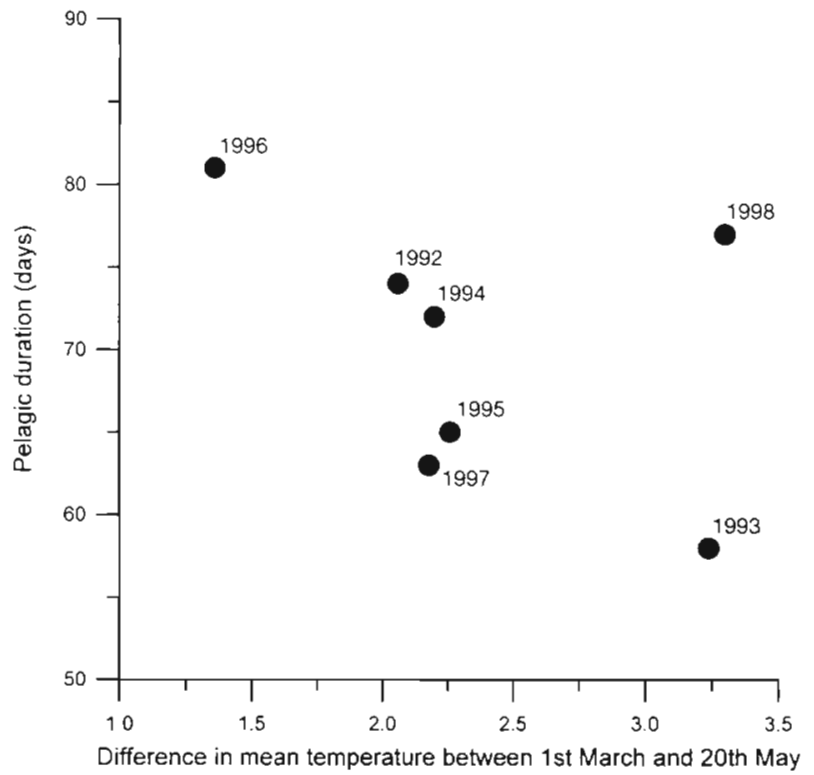

Fig. 10. Relationship between plaice pelagic stage duration and the rise in temperature between date of maximum Stage I egg production and $50 \%$ settlement in Port Erin Bay. Seawater temperatures from Fig. 9

\section{DISCUSSION}

Numerous factors influence the abundance of plaice at different life history stages and contribute to, or mediate, interannual variability in abundance. Some of these factors are related to characteristics of the spawning stock which can influence the location and timing of spawning, as well as the abundance of eggs produced.

There is a consistent pattern to the location of Stage I plaice eggs on the west side of the Isle of Man. The highest concentration of eggs is in the vicinity of Contrary Head. In this area there is a division between the north- and south-running tidal streams (D'Oliveira \& Featherstone 1998), suggesting either reduced tidal currents or a gyre. Therefore either the plaice spawn in this area and the eggs are generally retained, or the eggs are entrained into this area from nearby spawnings. Stage I eggs are less than 3 d old at ambient temperatures in March, suggesting that the high concentrations are a reflection of the spawning area rather than entrainment of eggs. The surveys of Stage I plaice eggs in 1995, covering the whole of the Irish Sea, indicate that there is a high similarity in the distribution of Stage I and Stage V plaice eggs. This suggests that there is little residual tidal flow at Irish Sea spawning grounds, i.e. off St. Bees Head, Great Orme Head and along the eastern Irish coast. This is in contrast to the plaice spawning in the Southern Bight of the North Sea, where the eggs are generally in an area of relatively high residual currents (Simpson 1959b, Harding 
Table 2. Variability in spawning stock biomass, Stage I egg production, numbers of individuals settling and population size in July for the Irish Sea and Port Erin Bay, and the Southern Bight of the North Sea. The lrish Sea data cover the period 1992 to 1998 (spawning stock biomass data from Anonymous 1998. Port Erin Bay populations size in July from Nash unpubl data). North Sea data (spawning stock biomass and Stage I egg production) are from 1957, 1962, 1963 , 1968, 1969, 1971 and 1987 to 1989 (Harding et al. 1978, Heessen \& Rijnsdorp 1989, van der Land et al. 1990. Anonymous 1996). North Sea data for peak at settling and population size in July on the Balgzand (Dutch Wadden Sea) from van der Veer et al. (1997). Note that in the North Sea the pelagic and nursery ground years do not necessarily correspond

\begin{tabular}{|llccc|}
\hline & CV & $\begin{array}{c}\text { Irish Sea } \\
\text { Variation } \\
\text { (\%) }\end{array}$ & $\begin{array}{c}\text { Nhighest/owest value) } \\
\text { (h) }\end{array}$ & $\begin{array}{c}\text { North Sea } \\
\text { Variation } \\
\text { (highest/lowest value) }\end{array}$ \\
\hline Spawning stock biomass & 13 & 1.5 & 9 & 1.3 \\
Stage I egg production & 36 & 2.8 & 40 & 3.3 \\
Numbers /peak $^{\mathrm{b}}$ settling & $72^{\mathrm{c}}$ & $7.1^{\mathrm{d}}$ & $62^{\mathrm{b}}$ & \\
Population size in July & 56 & 4.9 & 35 & \\
\hline
\end{tabular}

increases in productivity. Elevated levels of chlorophyll a fluorescence do not generally occur until the plaice larvae have already started to settle on the nursery grounds. Young plaice larvae are known to feed on phytoplankton (Last 1980), yet the phytoplankton concentrations between March and early May are generally low. Probably the major prey items for plaice larvae (at least in the North Sea) are appendicularians and copepod nauplii (Last 1980). Data for 1993 indicate that during the plaice larval phase on the west side of the Isle of Man these prey were at relatively low concentrations (Nicholas 1995). Gowen et al. (1998) also show that copepod abundance over much of the Irish Sea, including Irish coastal

et al. 1978, van der Veer et al. 1998). In the Irish Sea the nursery grounds are generally much closer to the spawning grounds, and therefore there may be an advantage to spawning near retention features so that eggs are not transported very far.

Peak egg production occurs at approximately the same time on the west coast of the Isle of Man as in the broader eastern Irish Sea. Simpson's (1959a) data suggest peak egg production in the eastern Irish Sea is around March 10 , which is consistent with the range of peak production times for the Isle of Man waters. The peak plaice egg production in the Southern Bight of the North Sea is generally earlier than the Irish Sea (Harding et al. 1978 . Rijnsdorp \& Vethaak 1997). The data from the west coast of the Isle of Man indicate that the timing of $50 \%$ of plaice Stage I egg production can vary by as much as $22 \mathrm{~d}$. The mid-point of egg production in the Southern Bight of the North Sea varies by approximately $30 \mathrm{~d}$, and in the German Bight by 23 d (Rijnsdorp \& Vethaak 1997). In both the North Sea and the Irish Sea, peak egg production tends to occur earlier, when the preceding August-to-December water temperatures are higher (data from Harding et al. 1978 and sea surface water temperatures for Den Helder, NIOZ pers. comm). Rijnsdorp \& Vethaak (1997) also related warmer water temperatures at spawning with earlier spawning times. This variability in the timing of spawning influences both the timing and shape of the settlement pattern on the nursery grounds (Hyder \& Nash 1998).

On the west side of the Isle of Man there is a link between the thermal regime and the timing of spawning. Warmer years could produce earlier primary and secondary production blooms, and plaice spawning time could be varying in synchrony with the production cycles. However, there isn't much variation in timing of peak spawning. Plaice spawn early in the season, prior to waters, does not increase substantially until late May each year. Despite the accepted statements concerning potential survival and match-mismatch of larvae and their food (Cushing 1969, 1990), it is clear that pelagic plaice survival is not linked to blooms in the same way as for some species (Cushing 1969, Houde 1997).

The data presented here demonstrate considerable variation in Stage I egg production for a given spawning stock. This variability in abundance is generated independently of spawning stock biomass. The age structure of a population can have a major influence on the numbers of eggs produced. Marshall et al. (1998) point out that the viability of cod eggs differs between first-time and repeat spawners. Therefore, over the medium term there can be a drift in the relationship between spawning stock biomass and viable egg production. This influences the perception of the relationship between spawning stock biomass and recruitment. Over and above changes in age structure, Rijnsdorp (1991) has shown changes in fecundity over time for North Sea plaice. Neither changes in age structure nor changes in fecundity can really explain the relatively large Stage I egg production in the west coast of the Isie of Man piaice population in 1992 and 1996. Variability in the numbers of eggs produced could be due to variability in the numbers of fish which spawn in the area, since this is a sub-population of the Irish Sea plaice stock. At present, we are unsure of the fidelity of individuals to specific spawning grounds.

We estimated that the west Isle of Man spawning contributes only $0.7 \%$ to the total egg production in the North Irish Sea, based on a direct comparison of egg production measured in 1995 (Anonymous 1997). Ellis \& Nash (1997) had estimated that annual egg production on the west side of the Isle of Man accounted for approximately $2 \%$ of the eggs spawned by the Irish Sea 
plaice stock, based on VPA estimates of stock size and fecundity-size relationships. VPA estimates of stock size were lower than estimates based on the egg production method (Anonymous 1997) for Irish Sea plaice, and consequently this affected the earlier calculations of egg production. Differences between VPA and egg production method estimates of stock size have been noted by a number of authors for other marine species (Bannister et al. 1974, Heessen \& Rijnsdorp 1989, Horwood 1993a,b).

Some of the variability in Stage I egg production could be caused by interannual variations in oocyte reabsorbtion, production of non-viable eggs and mortality of Stage I eggs. Mortality operating over the first 2 to $3 \mathrm{~d}$ after the eggs are spawned would be difficult to distinguish from variability in egg production. Nonetheless, apparent egg production varies considerably between years, but the underlying reasons need further investigation.

We found a direct relationship between the numbers of Stage I plaice eggs and the numbers of individuals that settle on the nursery grounds. This suggests that the variability generated on the nursery grounds originated either from the spawning stock or very early in the pelagic phase. The estimated pelagic stage duration (time from Prod Po $_{50}$ to $50 \%$ settlement) on the west coast of the Isle of Man varies between 58 and $81 \mathrm{~d}$. This is very similar to the pelagic drift period (60 to 80 d) for plaice eggs and larvae from the Southern Bight of the North Sea to the Wadden Sea nursery grounds (van der Veer \& Witte 1999).

The link between egg production and settlement contributes to interannual variability in abundance. However, there are processes occurring on the nursery ground that also affect juvenile plaice survival (van der Veer 1986), and these tend to reduce interannual variability in abundance. The interannual variability is highest at or around settlement, in agreement with van der Veer (1986), Beverton \& Iles (1992), and Nash (1998). The subsequent reduction in interannual variability in abundance by July supports the suggestion of regulatory processes operating through the nursery ground phase (van der Veer 1986, Nash 1998).

In 1996 high densities of juvenile plaice were measured both in Port Erin Bay and in the Wadden Sea (van der Veer \& Witte 1999). There may be frequent concordance between the 2 areas. However, in the North Sea the numbers at settlement are related to February water temperatures and drift, whereas in Port Erin Bay no such relationships exist.

In summary, it has been possible to examine the early stage population dynamics of plaice due to the close proximity of the spawning and nursery grounds and the relatively long time series of both Stage I egg production and settlement. The data presented here agree with the life history model for the young stages of plaice proposed by Beverton \& Iles (1992), whereby there is an increase in interannual variability in abundance between egg production and early stages on the nursery ground. Over the nursery ground phase there is a progressive reduction in interannual variability. There appears to be predictable environmental influences on the timing of Stage I egg production (spawning) and the duration of the pelagic phase. Importantly, there is a linear relationship between the numbers of Stage I eggs produced and the numbers of settling individuals on the local nursery ground, a relationship given in Nash (1998).

Acknowledgements. The authors are grateful to the crew of RV 'Roagan' for their assistance in this work. We are also grateful to Tim Ellis for access to his 1992-93 Stage I egg data and his 1992-93 nursery ground catch data; Kirsten Dau for permission to use her 1994 nursery ground catch data; Kirsty Nicholas for permission to use her 1994 chlorophyll $a$ and zooplankton data; the WISPER programme at the Port Erin Marine Laboratory for the chlorophyll a fluorescence data from the west side of the Isle of Man for 1996 to 1998; Emma Alesworth, Sara Taylor, Cheryl Corkill and Graham Hughes for working at sea, sorting and identifying plaice eggs from the samples, undertaking the nursery ground sampling and sample processing. We are also grateful to the General Secretary of ICES for permission to use the spawning stock biomass data for plaice, from the North Sea Demersal and the Northern Shelf Working Groups. Finally we are grateful to Mike Armstrong (DANI), Adriaan Rijnsdorp (RIVO) and Henk van der Veer (NIOZ) for constructive comments on earlier drafts of this paper.

\section{LITERATURE CITED}

Anonymous (1996) Report of the Working Group on the assessment of demersal stocks in the North Sea and Skagerrak. ICES CM 1997/Assess:6

Anonymous (1997) Estimation of fish biomass in the Irish Sea by means of the annual egg production method. Final Report. EC contract AIR3-CT94-2263

Anonymous (1998) Report of the Working Group on the Assessment of Northern Shelf Demersal Stocks. ICES CM 1999/ACFM:1

Apstein C (1909) Die Bestimmung des Alters pelagisch lebender Fischeier. Mitt Dtsch Seefisch 25:364-378

Bannister RCA, Harding D, Lockwood SJ (1974) Larval mortality and subsequent year-class strength in the plaice (Pleuronectes platessa L.). In: Blaxter JHS (ed) The early life history of fish. Springer, Berlin, p 21-37

Beverton RJH, Iles TC (1992) Mortality rates of O-group plaice (Pleuronectes platessa L.), dab (Limanda limanda L.) and turbot (Scophthalmus maximus L.) in European waters. III. Density-dependence of mortality rates of $\mathrm{O}$ group plaice and some demographic implications. Neth $J$ Sea Res 29:61-79

Coombs SJ, Nichols JH, Fosh CA (1990) Plaice eggs (Pleuronectes platessa L.) in the southern North Sea: abundance, spawning area, vertical distribution, and buoyancy. J Cons Int Explor Mer 47:133-139

Cushing DH (1969) The regularity of spawning season of some fishes. J Cons Int Explor Mer 33:81-92

Cushing DH (1990) Plankton production and year-class strength in fish populations: an update of the match mismatch hypothesis. Adv Mar Biol 26:249-293 
D'Oliveira B, Featherstone NL (eds) (1998) The Macmillan nautical almanac incorporating Reed's. Macmillan Publishers Ltd, London

Ellis TR, Nash RDM (1997) The timing and locations of spawning plaice Pleuronectes platessa L. around the Isle of Man, Irish Sea. ICES J Mar Sci 54:84-92

Gowen RJ, McCullough G, Dickey-Collas M, Kleppel GS (1998) Copepod abundance in the western Irish Sea: relationship to physical regime, phytoplankton production and standing stock. J Plankton Res 20:315-330

Harding D, Talbot JW (1973) Recent studies on the eggs and larvae of plaice (Pleuronectes platessa L.) in the Southern Bight. Rapp P-V Réun Cons Int Explor Mer 164:261-269

Harding D, Nichols $\mathrm{JH}$, Tungate DS (1978) The spawning of. plaice (Pleuronectes platessa L.) in the southern North Sea and English Channel. Rapp P.V Réun Cons Int Explor Mer 172:102-113

Hastings MH (1980) Aspects of the ecology of sandy-shore crustacea. PhD thesis, University of Liverpool

Heessen HJL, Rijnsdorp AD (1989) Investigations on egg production and mortality of cod (Gadus morhua L.) and plaice (Pleuronectes platessa L.) in the southern and eastern North Sea in 1987 and 1988. Rapp P-V Réun Cons Int Explor Mer 191:15-20

Horwood JW (1993a) Fecundity and biomass of plaice (Pleuronectes platessa L.) in the northern Celtic Sea. ICES J Mar Sci 50:315-323

Horwood JW (1993b) The Bristol Channel sole (Solea solea (L.)): a fisheries case study. Adv Mar Biol 29:215-367

Houde ED (1997) Patterns and consequences of selectivity processes in teleost early life histories. In: Chambers RC, Trippel EA (eds) Early life history and recruitment in fish populations. Chapman \& Hall, London, p 173-196

Hovenkamp $F$ (1989) Within-season variation in growth of larval plaice (Pleuronectes platessa L.). Rapp P-V Réun Cons Int Explor Mer 191:248-257

Hovenkamp F (1990) Growth differences in larval plaice Pleuronectes platessa in the Southern Bight of the North Sea as indicated by otolith increments and RNA/DNA ratios. Mar Ecol Prog Ser 58:205-215

Hyder K, Nash RDM (1998) Variations in settlement pattern of Irish Sea plaice (Pleuronectes platessa L.) as determined from a simulation model. J Sea Res 40:59-71

Last JM (1980) The food of twenty species of fish larvae in the west-central North Sea. MAFF Fish Res Tech Rep 60:44

Macer CT (1967) The food web in Red Wharf Bay (North Wales) with special reference to young plaice (Pleuronectes platessa). Helgol Wiss Meeresunters 15:560-573

Marshall CT, Kjesbu OS, Yaragina NA, Solemdal P, Ulltang $\varnothing$ (1998) Is spawner biomass a sensitive measure of the reproductive and recruitment potential of northeast Arctic cod? Can J Fish Aquat Sci 55:1766-1783

Nash RDM (1998) Exploring the population dynamics of Irish. Sea plaice, Pleuronectes platessa L., through the use of Paulik diagrams. J Sea Res 40:1-18

Nash RDM, Dickey-Collas M, Milligan SP (1998) Descriptions of the Gulf VII/PRO-NET and MAFF/Guildline unencased high-speed plankton samplers. J Plankton Res 20:1915-1926

Nicholas KR (1995) Secondary production of coastal plankton communities in the western Irish Sea. PhD thesis, University of Liverpool

Nichols JH, Haynes GM, Fox CJ, Milligan SP, Brander KM, Chapman RJ (1993) Spring plankton surveys of the Irish Sea in 1982,1985, 1987, 1988 and 1989: hydrography and the distribution of fish eggs and larvae. MAFF Fish Res Tech Rep 95

Pihl L. (1990) Year class strength regulation in plaice (Pleuro- nectes platessa L.) on the Swedish west coast. Hydrobiologia 195:79-88

Pommeranz T (1981) Observations on the predation of herring (Clupea harengus L.) and sprat (Sprattus sprattus L.) on fish eggs and larvae in the southern North Sea. Rapp P-V Réun Cons Int Explor Mer 178:402-404

Rijnsdoro AD (1989) Maturation of male and female North Sea plaice (Pleuronectes platessa L.). J Cons Int Explor Mer 46:35-51

Rijnsdorp AD (1991) Changes in fecundity of female North Sea plaice (Pleuronectes platessa L.) between three periods since 1900. ICES J Mar Sei 48:253-280

Rijnsdorp AD, Vethaak AD (1997) Changes in reproductive parameters of North Sea plaice and sole between 1960 and 1995. ICES CM 1997/U:14

Rijnsdorp AD, Daan N, van Beek FA, Heessen HJL (1991) Reproductive variability in North Sea plaice, sole and cod. $\mathrm{J}$ Cons Int Explor Mer 47:352-375

Riley JD, Symonds DJ, Woolner LE (1986) Determination of the distribution of planktonic and small demersal stages of fish in coastal waters of England and Wales and adjacent areas between 1970 and 1984. MAFF Fish Tech Rep 84:1-23

Russell FS (1976) The eggs and planktonic stages of British marine fishes. Academic Press, London

Ryland JS, Nichols JH, Sykes AM (1975) Effect of temperature on the embryonic development of the plaice, Pleuronectes platessa L. (Teleostei). J Exp Mar Biol Ecol 18: $121-137$

Shelbourne JE (1957) The feeding and condition of plaice larvae in good and bad plankton patches. J Mar Biol Assoc UK 36:539-552

Simpson AC (1959a) The spawning of plaice (Pleuronectes platessa) in the Irish Sea. Fish Invest Lond Ser II 22(8): $1-30$

Simpson AC (1959b) The spawning of plaice (Pleuronectes platessa) in the North Sea. Fish Invest Lond Ser II 22(7): $1-111$

van der Land MA, Heessen HJL, Rijnsdorp AD (1990) The results of the 1989 egg surveys for cod and plaice. ICES CM 1990/G:27

van der Veer HW (1986) Immigration, settlement and density-dependent mortality of a larval and early post-larval plaice (Pleuronectes platessa L.) population in the western Wadden Sea. Mar Ecol Prog Ser 29:223-236

van der Veer HW, Witte JIJ (1999) Year class strength of plaice Pleuronectes platessa L. in the Southern Bight of the North Sea: a validation and analysis of the inverse relationship with winter seawater temperature. Mar Ecol Prog Ser 184:245-257

van der Veer HW, Pihl L, Bergman MJN (1990) Recruitment mechanisms in North Sea plaice, Pleuronectes platessa. Mar Ecol Prog Ser 64:1-12

van der Veer HW, Ellis T, Miller JM, Pihl L, Rijnsdorp AD (1997) Size selective predation on juvenile North Sea flatfish and possible implications for recruitment. In: Chambers RC, Trippel EA (eds) Early life history and recruitment in fish populations. Chapman \& Hall, London, p 279-303

van der Veer HW, Ruardij P, van den Berg AJ, Ridderinkhof $H$. (1998) Impact of interannual variability in hydrodynamic circulation on egg and larval transport of plaice Pleuronectes platessa L in the southern North Sea. J Sea Res 39:29-40

Wennhage H, Gibson RN, Robb L (1997) The use of drop traps to estimate the efficiency of two metre beam trawls commonly used for sampling juvenile flatfishes. J Fish Biol 51:441-445

Zijlstra JJ, Witte JIJ (1985) On the recruitment of O-group plaice in the North Sea. Neth J Zool 35:360-376

Submitted: February 5, 1999; Accepted: June 16, 1999

Proofs received from author(s): November 1, 1999 